ISAAC AMON

\title{
The Timeless Quest for Truth in a World of Doubt: Re-Examining Modes of Proof in the Medieval Era
}

The life of the law has not been logic: it has been experience. The felt necessities of the time, the prevalent moral and political theories...have had a good deal more to do...in determining the rules by which men should be governed. The law embodies the theory of a nation's development through many centuries, and it cannot be dealt with as if it contained only the axioms and corollaries of a work of mathematics. In order to know what it is, we must know what it has been, and what it tends to become. ${ }^{1}$

Oliver Wendell Holmes, Jr.

\section{Introduction}

Man has always sought to locate certainty amidst doubt. Nowhere has this yearning been more fervent than in our longing for immortality and absolute truth. Like Juan Ponce De Leon's fabled voyage for the elixir of eternal youth more than five centuries ago, various methods and techniques were developed and utilized in the pursuit of objective reality, particularly to obtain that truth as seen from the divine perspective. This search for genuine certainty was never greater perhaps than in the Middle Ages, a period of extraordinarily intense religiosity that perme-

1 O.W. Holmes, Jr., The Common Law, Boston 1881, p. 1. 
ated every aspect of life, from womb to tomb. Everything remained the same and nothing would ever change. Indeed, as one historian rather wryly described it, "[medieval] [g]enerations succeeded one another in a meaningless, timeless blur." 2 Yet, the search for truth remained ever present.

Indeed, throughout human history, various investigative and adjudicative techniques arose to achieve this goal. We often assume that as methods are now, so must they have always been. This is not true, for the law does not exist in an "eternal present." It has been molded by external forces, circumstances, and events. Through a brief historical overview, this article seeks to re-examine modes of trial which predated by centuries the medieval creation of the grand jury and inquisition, among them the compurgation and the ordeal. By illuminating these earlier methods of discerning legal truth, this article shows how the nascent criminal justice system of medieval England (and Europe) progressed from depending upon divine judgments to human assessments of evidence, beginning with the Norman Conquest of England in October 1066.

By placing the coming framework within an historical context, this article shows how the Norman victory - under the leadership of William, Duke of Normandy - nearly a millennium ago irrevocably changed the history of criminal procedure. It then describes in greater detail the compurgation and the ordeal in medieval England, before concluding with the creation of the grand jury by King Henry II at the 1166 Assize of Clarendon, and the formal abolition of the ordeal by Pope Innocent III at the Fourth Lateran Council in 1215. A profound transformation to ascertain legal truth was underway as a new world was born. We still live in its throes today.

2 W. Manchester, A World Lit Only by Fire: The Medieval Mind and the Renaissance, Portrait of an Age, New York 1992, p. 23. 


\section{Norman Conquest}

In England, the progenitor of the common law, history quite often seems to begin with the Norman Conquest in October 1066. ${ }^{3}$ In January of that year, Edward the Confessor, King of the Anglo-Saxons, died after having ruled England for nearly twenty-five years. Immediately after his passing, controversy arose as to who should succeed him to the English throne. The local aristocracy, the Witenagemot (a council of the most important noblemen), ratified the succession claims of Harold Godwinson, Earl of Wessex, as opposed to those of Harald Hardrada, King of Norway or William, Duke of Normandy. Resolute in their claims to the English throne, these two challengers confronted Godwinson that autumn for supreme mastery of England on the battlefields of Stamford Bridge and Hastings. Although Godwinson decisively routed Hardrada at Stamford Bridge, he would be forced a mere fortnight later to confront the Norman challenger at Hastings.

The fundamental importance of this succession dispute, and the resulting consequences of the successful victory by William, Duke of Normandy over Harold Godwinson that fateful day is not that it marked the first successful invasion of England. Au contraire. Germanic tribes from Northern Europe and Viking incursions from Scandinavia had already permanently influenced centuries of developments of English history, culture, language, tradition and law (indeed, two German tribes, the Angles and Saxons, were the origins of the term Anglo-Saxon). ${ }^{4}$

3 For more detailed information on this momentous year, which witnessed the death of Edward the Confessor and the coronation of Harold Godwinson in January, the sighting and imagined ill-omen of Halley's Comet in April, and Godwinson's battles with Harald Hardrada of Norway and William, Duke of Normandy, at the battles of Stamford Bridge and Hastings, in September and October, followed by the triumphal coronation of William "The Conqueror" on Christmas Day, 1066, see D. Howarth, 1066: The Year of the Conquest, New York, 1978; K. DeVries, The Norwegian Invasion of England in 1066, Woodbridge, Suffolk and Rochester, New York 1999; and A. Bridgeford, 1066: The Hidden History in the Bayeux Tapestry, New York 2005.

4 As one medieval historian described it, "[t]he bonds between England and the Northern sphere of influence went far beyond the political. Anglo-Saxon weekdays were Tir's Day and Woden's Day and Thor's Day, not Mercury's Day and Mars' Day as it was in neighbor- 
Over the course of centuries, Viking invaders from Scandinavia had repeatedly invaded Britain, eventually leading to the installation of a Scandinavian monarch, Cnut (also referred to as Canute) in 1016, a half century before the Norman invasion and conquest. Ruler of a selfproclaimed Scandinavian or "North Sea” Empire, Cnut did not exaggerate, for he simultaneously ruled England, Norway, and Denmark. He was a quite competent ruler, reigning for nearly 20 years (r. 1016-1035), a mere half century before the Norman Conquest. Under his leadership, relationships were being created between these countries which might eventually have contributed to the continued dominance of his empire, had fate or chance allowed it to continue. Nonetheless, even on the very eve of the Norman Conquest, England remained firmly rooted within the Scandinavian cultural orbit. ${ }^{5}$

The outcome of Hastings on October 14, 1066 definitively ended any hopes of maintaining a version of this "North Sea” Empire. ${ }^{6}$ Thus,

ing France, a country under a long and heavy Roman influence...The English economy was tied to the vital North Sea trade routes: English goods went in Norse and Danish hulls across the North Sea to Danish and Swedish trading cities...From the perspective of 1066, England belonged more to Scandinavia than to the southern, Franco-Roman world across the stormy Channel.” (See C. Holland, Repulse at Hastings, October 14, 1066: William does not conquer England, in: The Collected What If? Eminent Historians Imagining What Might Have Been, ed. R. Cowley,, New York 2001, pp. 476-77. See that essay as a fascinating and rather provoking account of what would have happened if England had remained as part of Canute’s “Northern Empire,” instead of being influenced by French customs, laws, and ideas after the victorious Norman conquest).

5 Ibidem.

6 Ibidem, p. 484: "Few battles in all of history have been as decisive as Hastings. The outcome of those bloody hours on October 14, 1066, was to wrench England from the northern axis of Scandinavia and the North Sea around to a profound involvement with the Southern, Latin world. Henceforth the Northern world waned, and the Latin world blossomed into the glory of the High Middle Ages and the Renaissance. Hastings deserves its reputation as the greatest battle in English history, and a major turning point in the history of the world.” In addition, it should be noted that Scandinavian laws and customs were based on ancient Germanic customs and traditions, with variations based on time and place. It is quite clear, however, that a process of legal codification - essentially writing and recording local rules, customs and traditions - began in the twelfth century, not too long after Scandinavian influence had waned in England. This process gradually created a uniform and coherent body of laws, as power became centralized throughout the Scandinavian kingdoms. Criminal codes were drafted and revised during the next few centuries, ultimately leading 
that encounter represented not just the clash of two men, or even two countries, but a foundational fault-line between the frontiers of two different civilizations, which portended two entirely different futures for generations to come. The Norman Duke was victorious that October day, thus ensuring that the future development of history, culture, and law - including core criminal procedural guarantees - would be permanently and fatefully altered. ${ }^{7}$ Nearly a millennium later, the effects of that day remain, and are solemnly intoned before judicial proceedings commence everyday:

[I]f we enter the most humble [sic] court in any remote and newly-settled country in the American forests, a plain and rustic-looking man will call the equally rustic-looking assembly to order by rapping his baton, the only symbol of his office, on the floor, and calling out, in words mystic and meaningless to him, 'O yes! O yes! O yes!'* He little thinks that he is obeying a behest of William the Conqueror, issued eight hundred years ago, ordaining that his native tongue should be employed in the courts of England. ${ }^{8}$

Following his victory at Hastings, the Norman Duke confronted a mammoth task. William needed to begin the process of successfully integrating Norman laws and customs, based on Roman law, with those of an alien land and people, Anglo-Saxons, where the reach of Rome had

to closer political and legal integration among the Nordic countries. (See now: K. Zweigert and H. Kötz, An Introduction to Comparative Law, 3rd ed., transl. T. Weir, Oxford 1998, pp. 277-280).

7 M. Bishop, The Middle Ages, Boston 1987, p. 58: “October 14, 1066, was one of the decisive days of history...If Harold had won at Hastings...William would have had no choice but to renounce his adventure. There is little likelihood that anyone would have attempted a serious invasion of England during the next millennium - by water, at least. England would have strengthened its bonds with Scandinavia while remaining distrustful of the western Continent - even more distrustful than it is today. The native Anglo-Saxon culture would have developed in unimaginable ways, and William the Conqueror would be dimly known in history only as William the Bastard."

8 J. Abbot, History of William the Conqueror, New York 1899, reprint., 2012, p. 134: “(*Oyez! Oyez! Oyez! Norman French for Hearken! hearken! hearken!) 
never truly permeated. ${ }^{9}$ This gradual amalgamation, which continued after the death of William the Conqueror in 1087, found its greatest expression in his great-grandson, Henry II. One of the greatest medieval monarchs, who reigned for 35 years (r. 1154-1189), he became the singular figure in the formation of the common law throughout the realm. ${ }^{10}$

Accordingly, while the course of history was forever altered that autumn day, disregarding what came before 1066 fails to see the extraordinary longevity of man's search for truth. The medieval inquisition - and its later Spanish and Portuguese manifestations - along with the development of trial by jury principally arose due to the abolition of earlier, seemingly more primitive methods of seeking out the divine truth. Once these techniques (compurgation and ordeals) had been consigned to the dustbin of history, alternative methods were required to discover the truth, which led to the inquisition and cross-examination. ${ }^{11}$ Yet, to truly comprehend this enduring search for certainty, we must peer back into the mists of history and examine those earlier methods for obtaining truth, especially before the Norman victory at Hastings.

9 Ibidem, pp. 133-134: “[William] had, in fact, a Herculean task to perform - a double task viz., to amalgamate two nations, and also to fuse and merge two languages into one. He was absolutely compelled, by the circumstances under which he was placed, to grapple with both these vast undertakings...It was one of those cases where, being obliged to go far, it is best to go farther; and William resolved on thoroughly Normanizing, so to speak, the whole British realm. This enormous undertaking he accomplished fully and permanently; and the institutions of England, the lines of family descent, the routine of judicial and administrative business, and the very language of the realm, retain the Norman characteristics which he ingrafted into them to the present day."

10 M. Bishop, The Middle Ages, p. 59: "Then in 1154 Henry II came to the throne. He was the first Angevin king, son of Geoffrey Plantagenet, count of Anjou...Henry's great achievement was to lay the foundations of common law, on which English liberty and even the institution of limited monarchy rest. The common law is based on custom and usage, and is 'common' to the whole kingdom.” Interestingly enough, he was also the father of Richard I “The Lionheart” and King John, of Robin Hood fame and infamy, respectively.

11 In the immortal words of John Henry Wigmore, the legendary (and early 20th century) Dean of Northwestern University School of Law, "[cross-examination is] beyond any doubt the greatest legal engine ever invented for the discovery of truth" (5 J. Wigmore, Evidence § 1367, p. 32 (J. Chadbourn rev. 1974)). Quoted in Lilly v. Virginia, 527 U.S. 116, 123 (1999); Nix v. Whiteside, 374 U.S. 157, 158 (“The very nature of a trial is [the] search for truth.”). 


\section{Compurgation}

"In the Anglo-Saxon period justice was administered mainly in the local popular tribunals of the shire, hundred, and borough, and the most common forms of trial were compurgation and the ordeal of fire or water." 12 The method of compurgation entailed that the accused gathered together a certain number of his neighbors, who knew him personally, to stand by his side in the face of criminal allegations. These individuals, labeled "compurgators," were fundamentally "oaths-helpers who swore, not that the accused was innocent, but that his oath was to be believed.”13

Most significantly, this method of proof had the formal approbation of the Church. Indeed, "[t]he right of the diocesan bishop to assign purgation in criminal cases had been the subject of the papal decretal Nos inter alios, the basis (according to most canonists) of the Church's jurisdiction over secular crime.” ${ }^{14}$ Once the accused had accumulated a sufficient number of compurgators, he was compelled to formally swear, in front of them, that he was innocent of the charges. The character of the accused was of utmost importance, for that was what the compurgators swore to before God, clergy, and members of their local community. ${ }^{15}$

Canon law (further proof that foreign law influenced the development of English law) dictated the procedures governing the usage of compurgation, and later on, in trials of ordeal. There first had to be "preexisting public fame that the accused had committed a crime. Without public fame, he could not be put to compurgation." 16 Most conclusively,

12 C. Gross, Modes of Trial in the Mediceval Boroughs of England, "Harvard Law Review" 1902, vol. 15, no. 9, p. 691.

13 R. Hudson, The Judicial Reforms of the Reign of Henry II, “Michigan Law Review” 1911, vol. 9, no. 5, p. 387.

14 R.H. Helmholz, Crime, Compurgation and the Courts of the Medieval Church, "Law and History Review" 1983, vol. 1, no. 1, p. 13. "The compurgators swore not to the truth of the underlying facts, but to their belief in the trustworthiness of the oath of the accused."

15 Ibidem. Helmholz further notes that “[a]lthough they were not simple 'character witnesses' as is sometimes said by critics of the ecclesiastical tribunals, compurgators were not required to know the underlying facts. It was enough that they could conscientiously swear to their belief in the oath of the accused. His character certainly entered into the picture.”

16 Ibidem. 
"the suspicion must be held by good and substantial persons before further proceedings could occur." 17 The compurgators had to be "of good repute, free from public crime or infamia"18 or "good and true men (legales homines) of the borough." ${ }^{19}$ Both parties to the dispute ordinarily needed to be present; absence of one side was taken as an admission of guilt. ${ }^{20}$ As one scholar phrased it, "failure in compurgation was equivalent to conviction or confession." ${ }^{21}$ Either side could further be deemed to lose the purgation process, "if in reciting word-for-word the customary formula [they] omitted the right word or phrase.”22

This method of testimonial oath-taking was not only strongly rooted in primitive English law, but “[o]athing resisted strongly the influences of Roman and Scandinavian law, and for several centuries testimony affirmed by an oath existed side-by-side with more advanced judicial methods of weighing evidence, such as trial by jury."23 It is not surprising that compurgation existed as long as it did, particularly in more primitive societies, where communities were small, individuals lived their lives in the same small part of the world they were born into, and status reigned supreme. ${ }^{24}$ In addition to one's social position, religion held uppermost sway, and belief was widespread that "the oathtaker swearing upon a relic would immediately be stricken down senseless or rendered

17 Ibidem, p. 14.

18 Ibidem, p. 17.

19 C. Gross, Modes of Trial..., p. 698. As he further observes (on pp. 698-699): "The Customal of Sandwich, speaking of the plea of debt, says that if any of them [compurgators] have been convicted of perjury, have performed public penance, or have conspired against their lord, and have fled hither, or are fugitives for murder or theft, or if a son is produced to swear for the father or a servant for his master, or if a man is an enemy of the defendant, such persons cannot be admitted to prove or acquit upon a challenge."

20 W. Shack. Collective Oath: Compurgation in Anglo-Saxon England and African states. "European Journal of Sociology" 1979, vol. 20, no. 1, p. 7.

21 Ibidem, p. 8.

22 Ibidem.

23 Ibidem, p. 2.

24 Ibidem, p. 17. "Justice in Anglo-Saxon England aimed primarily towards maintaining the status system of social positions that obtained between lords, freemen, serfs, and bondsmen, and the application of justice reflected those social ideas concerning rights and privileges that justified the system.” 
rigid and motionless in the act of swearing falsely...[thus] compurgation became almost an ordeal of itself."25

Furthermore, as the notion of individual rights did not yet exist, this method of proof brought "about a temporary modicum of peace between the two sets of disputants, backed by their kinsmen[,]" and "lessened the demands for an immediate wager of armed strength[.]"26 Most of the accused who underwent this process cleared their names. Indeed, the number has been estimated that as many as three quarters successfully did so, and even if the accused was found guilty, after failing to clear his name via compurgation, the ecclesiastical sanction was that of public penance. ${ }^{27}$ Not surprisingly, this method of proof "[failed] to inspire confidence as a fact-finding device[,]"28 and another method of proof was consequently needed to replace that of compurgation. ${ }^{29}$

The method chosen was that of trial by ordeal, sanctioned by the Church for several centuries, until its abolition by the Fourth Lateran Council in 1215. King Henry II in his famous Assizes or Constitutions of Clarendon in 1166 promulgated the ancestor of today's modern grand jury. ${ }^{30}$ "In that year, the Assize of Clarendon" observed Roger D. Groot, "ordained the selection and swearing of twelve lawful men of each hundred; four such men were also to be selected from each vill.”31 Anyone suspected of having committed a crime - thus satisfying the canonical standard of public notice or infamia - would be reported by

25 Ibidem, p. 8.

26 Ibidem, p. 6.

27 R.H. Helmholz, Crime, Compurgation..., p. 19.

28 Ibidem.

29 M.H. Kerr, R.D. Forsyth and M.J. Plyley, Cold Water and Hot Iron: Trial by Ordeal in England, "The Journal of Interdisciplinary Review” 1992, vol. 22, no. 4, p. 574. "Piety, psychological testing, finality, certainty, punishment, deterrence - all these have been put forward as reasons for the ordeal's use in the English criminal justice system.”

30 R.H. Helmholz. The Early History of the Grand Jury and the Canon Law, "The University of Chicago Law Review” 1983, vol. 50, no. 2, p. 613.

31 R.D. Groot, The Jury of Presentment before 1215, “The American Journal of Legal History” 1982, vol. 26, no. 1, p. 3. 
these jurors to the sheriff's court and then to the royal justices, whereupon the accused would then undergo the ordeal. ${ }^{32}$

"Compurgation is thought to have disappeared" one scholar speculated in the late nineteenth century, "in consequence of what has been called the 'implied prohibition' of the Assize of Clarendon, in 1166. But it remained long in the local and in the ecclesiastical courts." ${ }^{33}$ Indeed, the Houses of Parliament did not formally abolish "wager of law” until 1833, the very year they abolished slavery throughout the British Empire. ${ }^{34}$

\section{Ordeal}

Though known among the Greeks, the ordeal was unknown among the Romans. It was principally "found among the Germanic peoples, in Germany itself as well as in the old Roman Provinces of Gaul, Italy and Britain." 35 At its core, it "was an appeal to the supernatural for aid in deciding questions too difficult for man's wisdom.”36 Consequently (and perhaps not surprisingly), a correlation can be drawn between the increasing conversion rate of pagan tribes to Christianity along with the gradual decline and replacement of compurgation with that of the ordeal. ${ }^{37}$ Yet, as one scholar notes, Anglo-Saxon tradition already recognized modes of ordeal:

The four ordeals known to Anglo-Saxon law were the ordeal of hot iron, the ordeal of hot water, the ordeal of cold water, and the ordeal of the morsel. In the first of these ordeals, the accused was required to carry hot

32 Ibidem. See also: R. Hudson, Judicial Reforms..., p. 388, where the author says: “A sworn jury of neighbors is such a simple and obvious method of discovering facts that at first sight it seems scarcely necessary to inquire as to its history."

33 J.B. Thayer, The Older Modes of Trial, "Harvard Law Review” 1891, vol. 5, no. 2, p. 59.

34 Ibidem, p. 63. Thayer references (Stat. 3 \& 4 Will. IV. c. 42 s. 13).

35 S. Eidelberg, Trial by Ordeal in Medieval Jewish History: Laws, Customs and Attitudes, "Proceedings of the American Academy for Jewish Research" 1979, vol. 46/47, p. 106.

36 R. Hudson, Judicial Reforms..., p. 387.

37 S. Eidelberg, Trial by Ordeal..., p. 106. 
iron in his hand for nine days. If at the end of three days the hand had festered he was guilty, not innocent. If the ordeal of hot water was used the accused was required to plunge his hand into hot water as far as the wrist or even to the cubit, the former if the ordeal was simple, the latter if threefold. If the accused was thrown into cold water he was adjudged innocent if he sank, guilty if he floated. If the ordeal of the morsel was used a piece of bread of cheese weighing an ounce was given to the accused after having been adjured to stick in his throat if he was guilty. ${ }^{38}$

To this list, the Norman conquerors added judicial combat, or trial by battle. ${ }^{39}$ Though foreign to Anglo-Saxon tradition, trial by combat existed for nearly eight centuries. Parliament did not formally abolish it until 1819, the year of Queen Victoria's birth. ${ }^{40}$ Though the rituals of compurgation and trial by ordeal appeared drastically different, the essence was not, for both modes of proof depended upon "the [sincere] belief that a just and omnipotent God would not permit an innocent person to be convicted and punished. Rather, He would intervene and proclaim the truth, even by miracles if need be." 41

Although these methods of discerning truth (particularly ordeals) may appear repugnant to the modern conscience, this is a result of the Enlightenment era. ${ }^{42}$ Consequently, in the exceedingly religious milieu

38 R. Hudson, Judicial Reforms..., p. 388.

39 Ibidem. See also: J.B. Thayer, The Older Modes of Trial, pp. 65-66: “This is often classified as an ordeal, 'God's judgment.'....it survived the ordeal proper for centuries...Although it existed among almost all the Germanic people, the Anglo-Saxons seem not to have had it; but it came into England with the Normans in full strength...There is sufficient evidence that it was, at first, a novel and hated thing in England. In the so-called 'Laws of William the Conqueror,' it figures as being the Frenchman's mode of trial, and not the Englishman's."

40 J.B. Thayer, The Older Modes of Trial, p. 70: “And now at last, in June 1819, came the abolition of a long-lived relic of barbarism, which had survived in England when it had vanished everywhere else in Christendom."

41 S. Eidelberg, Trial by Ordeal..., p. 105.

42 J.B. Thayer, Older Modes of Trial, pp. 63-64: “As the investigations of scholars discover it everywhere among barbarous people, the conclusion seems just that it is indigenous with the human creature in the earlier stages of his development. Like the rest, our ancestors had 
of an earlier age, the replacement of compurgation by the ordeal would not necessarily have been considered shocking (just as the continental inquisition and common law trial by jury should not be regarded as radically inapposite in more recent times) as their key objective remained the same. In other words, "[w]hen...we remember that compurgation and the ordeals were for centuries made use of by the English courts[,] we begin to see that what seems obvious has not necessarily existed everywhere and from all time." ${ }^{43}$

A remarkably skeptical account of the divine origins of the ordeal comes down to us from the days of William II (Rufus). A mere few decades after the Norman Conquest of 1066, fifty men were subjected to the ordeal of hot iron, and all apparently escaped unscathed. Whereupon, the son and successor to William the Conqueror, rejected this apparently divine verdict of not guilty and proclaimed that "he would try them again by the judgment of his court, and would not abide by the pretended judgment of God." ${ }^{44}$ This monarchical defiance (with double jeopardy implications) continued into the reign of Henry II, who similarly "would not allow an acquittal awarded on the basis of trial by ordeal to prevent the possibility of a second trial." 45 In other words, as the great English legal historians Pollock and Maitland observed, "Henry II had declared [that] when an indicted man came clean from the water, he was none the less to abjure the realm, if his repute among his neighbors was of the worst." ${ }^{\prime 4}$

it...This was found to be a convenient last resort, not only when the accused was old or disabled from fighting in the duel, but when compurgators or witnesses could not be found or were contradictory, or for any reason no decision could otherwise be reached."

43 R. Hudson, Judicial Reforms..., p. 388.

44 See Reeve's History of the English Law, ed. Finlason, 1869, vol. I, p. 234, as cited in J.A. Sigler, A History of Double Jeopardy, “The American Journal of Legal History” 1963, vol. 7, no. 4, p. 286.

45 See The Laws of King Ethelred III, 6 transl. in Ancient Laws and Institutes of England (Commissioners of the Public Records of the Kingdom, 1840) as referenced in Sigler, Double Jeopardy, p. 286, fn. 18.

46 F. Pollock Sir and F.W. Maitland, The History of English Law: Before the Time of Edward I. 2nd ed., vol. ii, London 1898. Reprint, Cambridge 1968, p. 599. 
One scholarly view, seemingly supported by statistics from the rolls of the ordeals of the late 12th and early 13th centuries, asserts that the exceptionally high rate of passage was indeed due to human manipulation (as William II and Henry II had averred) but its rationale was "an instrument of mercy." ${ }^{47}$ Success was thus due not to divine intervention or administrative incompetence, ${ }^{48}$ but "the ordeals themselves were engineered to ensure a high rate of success." ${ }^{49}$

The crimes tried ordeal, the pleas of the crown, were punishable by death or mutilation. One might therefore expect to see a reasonable number of accused convicted by the ordinary form of trial and punished as mandated by law. In the study of nearly 275 presentments (public prosecutions) from the eyres between 1194 and 1208, an accused was put to death or maimed in only eight recorded cases. Of these eight cases, four depended on a confession, one on failure as an approver, one on possession of stolen goods, one simply on suspicion (where the accused was too young to go to the ordeal), and just one on failure at the ordeal. ${ }^{50}$

It is therefore not without foundation to claim that the ordeal's true "purpose was to give the accused an opportunity to save his life." ${ }^{11}$ As evidence, it was asserted that due to the respective physical sizes of men and women, "a woman was much less likely than a man to pass the

47 M.H. Kerr et. al., Cold Water and Hot Iron..., p. 574. "Piety, psychological testing, finality, certainty, punishment, deterrence - all these have been put forward as reasons for the ordeal's use in the English criminal justice system."

48 Shack, Collective Oath: Compurgation in Anglo-Saxon England and African states, p. 17. "Historians have struggled to draw inferences based upon scanty records about the interdependency between certain legal ideas and modes of behavior in early times; anthropologists have struggled to reconstruct the past from inquiry into and observations of the present.”

49 M.H. Kerr et. al., Cold Water and Hot Iron..., p. 580. See also: F. Pollock Sir and F.W. Maitland, The History of English Law..., vol. II, p. 599, fn. 2: "Of fifty men sent to the ordeal of iron all had escaped. This certainly looks as if some bishop or clerk had preferred his judgment to the judgment of God, and the king [William II Rufus] did well to be angry.”

50 M.H. Kerr et. al., Cold Water and Hot Iron..., p. 578.

51 Ibidem, p. 588. 
ordeal of cold water." 52 Accordingly, women appear to rarely have been subjected to the ordeal of water, and those who suffered it were less likely to survive. ${ }^{53}$ The rolls of the ordeals further confirm that "[o]f a total of eighty-four men recorded as having been ordered to an ordeal in a public prosecution, seventy-nine are known to have gone to the ordeal of cold water...[while]... of seven women sent to trial on presentment, all were sent to the order of hot iron." ${ }^{54}$ Even if this scholarly assertion can be disproven or is simply rejected, one certainty remains: "The English church and government of the reigns of Henry II, Richard I, and John would be greatly puzzled if they knew that modern historians have sometimes looked upon the ordeal as a barbarity worse than capital punishment." 55

However, in November 1215, five months after the Magna Carta was signed by King John at Runnymede, the Fourth Lateran Council convened in Rome under the aegis of Pope Innocent III. It promulgated rules which "gradually reshaped the institutional and spiritual framework of European society." 56 The Lateran Council condemned all dissenting opinions from Catholic orthodoxy as "heresy," ordered those who held those opinions formally excommunicated and "extended [the stigma of heresy] to those who sheltered or defended its adherents, and to magistrates who failed to act against them." ${ }^{57}$ Jews were required to out-

52 Ibidem, p. 582.

53 J. Wijaczka, The Cold Water Ordeal (Swimming) in Witchcraft Accusations and Trials in the Polish-Lithuanian Commonwealth in the Sixteenth-Eighteenth Century, transl. by Natalia Klopotek, “Odrodzenie i Reformacja w Polsce” 2016, vol. 60, pp. 73-110.

54 M.H. Kerr et. al., Cold Water and Hot Iron..., p. 581.

55 Ibidem, p. 595.

56 R.I. Moore, The Formation of a Persecuting Society: Authority and Deviance in Western Europe 950-1250, 2nd ed. Malden, MA, 2007, p. 7.

57 Ibidem. For further information on the rise of heretical Christian movements, see D. Christie-Murray, A History of Heresy, 2nd ed. Oxford, 1991, p. 108: "Few heresies could survive against the power of the orthodox, once the Catholic Church flexed its muscles. Even if locally stronger they lacked the organization to oppose the juggernaut hierarchy of Rome backed by the civil power. Formal condemnation put them outside the law...The Inquisition and the use of the civil arm were finally too much for them. By about 1350, the heresies of the twelfth and thirteenth centuries were mostly dead." 
wardly distinguish themselves from Christians through garb and were barred from public office, and Jewish converts to Christianity were proscribed from practicing their former rituals, which the inquisition was later created to ferret out, vigorously monitor, and ultimately suppress. ${ }^{58}$

Further, this Council segregated lepers via expulsion or imprisonment, confiscated their property (as also occurred with heretics) and stripped them of all legal rights and remedies. "For all imaginative purposes heretics, Jews and lepers were interchangeable," ${ }^{29}$ for all these groups - enemies of the Christian order - undermined fraternal solidarity and sowed chaos throughout Christendom. And, when "the eighteenth [canon] abolished use of hot water and red-hot iron in trials by ordeal[,]"60 their operation gradually began to disappear. Nonetheless, it would take centuries for the ordeal to fully vanish from European soil, as demonstrated by several late 17th and early 18th century witchcraft cases in the Polish-Lithuanian Commonwealth. ${ }^{61}$

A new world was dawning and consequently the search for truth and those charged with uncovering it required additional methods to examine individuals. Thus, at this point in time, the continental and common law legal traditions, borne out of similar origins, went down alternative paths - leading to the inquisition and cross-examination - which permanently changed history. ${ }^{62}$

58 Ibidem. See also: D. Nirenberg, Communities of Violence: Persecution of Minorities in the Middle Ages, Princeton, 1996, p. 133.

59 Ibidem, p. 61.

60 J.J. Norwich, Absolute Monarchs: A History of the Papacy, New York 2011, p. 179.

61 J. Wijaczka, The Cold Water Ordeal...

62 R.D. Groot, The Jury of Presentment..., p. 1. “The procedural void thus created was filled on the continent by the confession...reliance on the confession as proof led to torture to obtain it. But in England the void was filled by the jury verdict as proof.” See also: L.W. Levy, Origins of the Fifth Amendment: The Right Against Self-Incrimination, New York 1968, pp. 272-273: "What accounts for England's singular escape from the fate of the continental nations of Europe? The most likely answer is that the accusatorial system of procedure, based on the inquest, effectively served the needs of the state, making unnecessary the employment of the inquisitorial system. Fortuitous timing seems to have made a great difference.... Not only was English law centralized early; the English state itself was centralized earlier than that of any other country, and one of the foremost means of achieving that cen- 


\section{Conclusion}

Today, the modern world in general, and the criminal justice system in particular, have largely and quite tragically forgotten this legal history. While vestiges of memories remain, their origins recede ever farther, even from the minds of learned votaries of the law, into antiquity. Much scholarship on the Middle Ages has focused on the inquisition and the common law trial by jury, which have frequently been framed as being in direct opposition to one another. Nonetheless, this analysis has often overlooked the exceedingly important rituals of compurgation and the ordeal whose elimination gradually led to the formation of the inquisition and the common law jury. Continued study of our shared historical, cultural, and societal origins will better inform the practitioner and academic as to the long and tortuous road that the search for truth has traveled. And, in this pursuit, it is incumbent upon all those in the legal profession to study its history:

Everyone should know something of our law...for our law is the protector of society, the safeguard of our rights, and the rule of our daily life... and the student can be assured...in this study 'There be delights, there be recreations and jolly pastimes that will fetch the day about from sun to sun, and rock the tedious year as in a delightful dream. ${ }^{63}$

tralization was the system of royal justice employing the inquest which became the grand and petty juries... Thus the jury system spread as rapidly and as widely as the justice of the royal courts, and as the rules of that common law which those courts were both making and administering. But the rapidity of the development of the common law caused it to produce a set of fixed principles before the ideas of the civil and canon lawyers had time to exercise an overwhelming influence upon the substance of its rules."

63 J.M. Gest, The Influence of Biblical Texts upon English Law, "University of Pennsylvania Law Review and American Law Register” 1910, vol. 59, no. 1, pp. 16-17. 


\section{References}

Abbot J., History of William the Conqueror, New York 1899.

Bingham T., Widening Horizons: The Influence of Comparative Law and International Law on Domestic Law, Cambridge 2010.

Bishop M., The Middle Ages, Boston 1987.

Bridgeford A., 1066: The Hidden History in the Bayeux Tapestry, New York 2005.

Brundage J., The Rise of Professional Canonists and the Development of the ius Commune. "Zeitschrift der Savigny-Stiftung für Rechtsgeshichte (KA)” 1995, vol. 81.

Christie-Murray D., A History of Heresy, 2nd ed. Oxford 1991.

Coleman-Norton P.R., Why Study Roman Law? “Journal of Legal Education” 1950, vol. 2, no. 4.

Colman, R.V. Reason and unreason in Early Medieval Law, "The Journal of Interdisciplinary History” 1974, vol. 4, no. 4.

Damaška M., The Quest for Due Process in the Age of Inquisition, “The American Journal of Comparative Law” 2012, vol. 60, no. 4.

David R. and Brierley J.E.C., Major Legal Systems in the World Today, 2nd ed., London 1978.

DeVries K., The Norwegian Invasion of England in 1066. Woodbridge, Suffolk-Rochester, New York 1999.

Eidelberg S., Trial by Ordeal in Medieval Jewish History: Laws, Customs and Attitudes, "Proceedings of the American Academy for Jewish Research” 1979, vol. 46/47.

Gest J.M., The Influence of Biblical Texts upon English Law, "University of Pennsylvania Law Review and American Law Register” 1910, vol. 59, no. 1.

Glenn H.P., Legal Traditions of the World: Sustainable Diversity in Law, 4th ed., Oxford 2010.

Groot R.D., The Jury of Presentment before 1215, “The American Journal of Legal History” 1982, vol. 26, no. 1.

Gross C., Modes of Trial in the Mediaeval Boroughs of England, "Harvard Law Review” 1902, vol. 15, no. 9. 
Hanson E., Torture and Truth in Renaissance England. "Representations” 1991, no. 34.

Head J.W., Great Legal Traditions: Civil Law, Common Law, and Chinese Law in Historical and Operational Perspective, Durham, NC, 2011. Helmholz R.H., Crime, Compurgation, and the Courts of the Medieval Church, "Law and History Review" 1983, vol. 1, no. 1.

Helmholz R.H., The Early History of the Grand Jury and the Canon Law, "The University of Chicago Law Review” 1983, vol. 50, no. 2.

Ho H.L., The Legitimacy of Medieval Proof, "Journal of Law and Religion” 2003-2004, vol. 19, no. 2.

Holland C., Repulse at Hastings, October 14, 1066: William does not conquer England, in: The Collected What If? Eminent Historians Imagining What Might Have Been, ed. R. Cowley, New York 2001.

Holmes Jr. O.W., The Common Law, Boston 1881.

Howarth D., 1066: The Year of the Conquest, New York 1978.

Hudson R., The Judicial Reforms of the Reign of Henry II, "Michigan Law Review” 1911, vol. 9, no. 5.

Kelley D.R., History, English Law and the Renaissance, "Past \& Present” 1974, vol. 65.

Kelly H.A., Inquisition and the Prosecution of Heresy: Misconceptions and Abuses, "Church History" 1989, vol. 58, no. 4.

Kerr M.H., Forsyth R.D. and Plyley M.J., Cold Water and Hot Iron: Trial by Ordeal in England, "The Journal of Interdisciplinary Review" 1992, vol. 22, no. 4.

Lawson M.K., Cnut: The Danes in England in the Early Eleventh Century, London 1993.

Levy L.W., Origins of the Fifth Amendment: The Right Against SelfIncrimination, New York 1968.

Manchester W., A World Lit Only by Fire: The Medieval Mind and the Renaissance, Portrait of an Age, New York 1992.

McAuley F., Canon Law and the End of the Ordeal, "Oxford Journal of Legal Studies” 2006, vol. 26, no. 3. 
Nirenberg D., Communities of Violence: Persecution of Minorities in the Middle Ages, Princeton 1996.

Mäkinin V., Pihlajamäki H., The Individualization of Crime in Medieval Canon Law, "Journal of the History of Ideas" 2004, vol. 65, no. 4.

Moore R.I., The Formation of a Persecuting Society: Authority and Deviance in Western Europe 950-1250, 2nd ed., Malden, MA, 2007.

Norwich J.J., Absolute Monarchs: A History of the Papacy, New York 2011.

Palmer B.W., An Imperishable System: What the World Owes to Roman Law, “American Bar Association Journal” 1959, vol. 45, no. 11.

Peters E., Inquisition, Berkeley-Los Angeles 1989.

Planck J.W., The Survival of Roman Law. "American Bar Association Journal” 1965, vol. 51, no. 3.

Ploscowe M., The Development of Present-Day Criminal Procedures in Europe and America, "Harvard Law Review" 1935, vol. 48, no. 3.

Pollock Sir F. and F.W. Maitland, The History of English Law: Before the Time of Edward I, 2nd ed., vol. ii, London 1898. Reprint, Cambridge 1968.

Ramage C.J., Roman Law, “The VirginiaLaw Review”1922, vol. 7, no. 12.

Seipp D.J., The Reception of Canon Law and Civil Law in the Common Law Courts before 1600, “Oxford Journal of Legal Studies” 1993, vol. 13, no. 3.

Shack W.A., Collective Oath: Compurgation in Anglo-Saxon England and African states, "European Journal of Sociology” 1979, vol. 20, no. 1.

Sigler J.A., A History of Double Jeopardy, "The American Journal of Legal History” 1963, vol. 7, no. 4.

Shoemaker K., The Devil at Law in the Middle Ages, "Revue De L'histoire Des Religions” 2011, vol. 228, no. 4.

Thayer J.B., The Older Modes of Trial, "Harvard Law Review” 1891, vol. 5, no. 2.

Wigmore J.H., The Privilege against Self-Crimination: Its History, “Harvard Law Review” 1902, vol. 15, no. 8. 
Williams I., The Tudor Genesis of Edward Coke's Immemorial Common Law, 'The Sixteenth Century Journal” 2012, vol. 43, no. 1.

Wijaczka J., The Cold Water Ordeal (Swimming) in Witchcraft Accusations and Trials in the Polish-Lithuanian Commonwealth in the Sixteenth-Eighteenth Century, transl. by Natalia Klopotek, “Odrodzenie i Reformacja w Polsce” 2016, vol. 60.

Zweigert K., Kötz H., An Introduction to Comparative Law, 3rd ed., transl. T. Weir, Oxford 1998.

\section{SUMMARY}

\section{The Timeless Quest for Truth in a World of Doubt: Re-Examining Modes of Proof in the Medieval Era}

This article presents a brief overview of historical methods of legal proof prior to and soon after the Norman Conquest of England in October 1066. Through an examination of the rituals of compurgation and the ordeal, which were techniques designed to discover truth prior to the establishment of the inquisition in medieval Europe and the common law jury trial in England, the human quest for intellectual conviction has been indelibly with us since the days of antiquity. And, whichever method to ascertain truth is ultimately utilized - compurgation or ordeal, inquisition or cross-examination, trial by judge or by jury - the law's enduring search for certainty amidst a world of doubt owes much to the history and times of William the Conqueror.

Keywords: law, criminal procedure, compurgation, ordeal, truth.

Isaac Amon, Researcher and Attorney \& Counselor at Law, St. Louis, Missouri, United States of America, e-mail: isaacamonlaw@gmail.com.

DOI 10.14746/ppuam.2020.11.08 